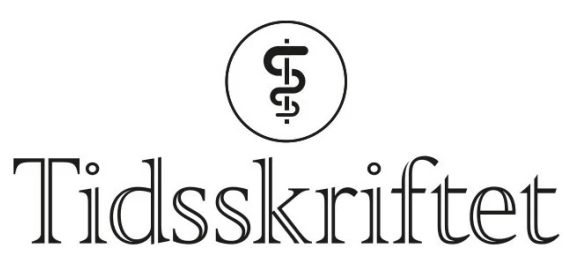

DEN NORSKE LEGEFORENING

\title{
Fra informert til fordekt samtykke?
}

NYHETER

\section{OLA BERGER}

Email: bergerola@gmail.com

Norges teknisk-naturvitenskapelige universitet

\section{De siste 20 årene har pasientinformasjonsskriv i kreftstudier blitt dobbelt så lange. Denne utviklingen krever mer kompetente lesere og kan føre til at et informert samtykke ikke er reelt.}

Pasientinformasjonsskriv for kliniske kreftstudier er lange og komplekse og vanskelige å lese og forstå. Vi ønsket å undersøke om lengden og innholdet har endret seg de siste 20 årene (1).

87 pasientinformasjonsskriv fra onkologiske studier godkjent av Regional komité for medisinsk og helsefaglig forskningsetikk (REK), Midt-Norge i perioden 1987-2007 ble identifisert. Utvalget besto av alle skriv fra fase 2-studier og fase 3-studier $(\mathrm{n}=41)$ samt tilfeldig utvalgte skriv fra de ulike årene $(n=46)$.

Vi identifiserte 47 spesifiserte innholdselementer for informasjonsskriv fra veiledere om innholdet i pasientinformasjonsskriv. 17 ble kategorisert som grunnleggende innholdselementer om fundamentale medisinske og etiske aspekter, mens zo ble kategorisert som formelle innholdselementer slik som juridiske aspekter, finansiering, forsikring, datasikkerhet og datalagring. Antall ord og innholdselementer ble så undersøkt i de 87 pasientinformasjonsskrivene.

Den gjennomsnittlige lengden $\emptyset$ kte fra 338 ord i 1987-9o til 1087 ord i 2005-07, mens antall innholdselementer $ø \mathrm{kte}$ fra ni til 25 . Antall grunnleggende innholdselementer $ø \mathrm{kte}$ fra sju i 1987-89 til 14 i 2005-07, mens antall formelle innholdselementer $\emptyset \mathrm{kte}$ fra to til 11.

Dagens skriv er så lange og kompliserte at man kan spørre om de fyller sin egentlige hensikt. Dette er en internasjonal utvikling som sannsynligvis skyldes at juridiske aspekter er blitt minst like viktige som de etiske. Det er behov for klarere internasjonale retningslinjer som sikrer lesbare pasientinformasjonsskriv og dermed større mulighet for å innhente et reelt informert samtykke. 
LITTERATUR

1. Berger O, Grønberg BH, Sand K et al. The length of consent documents in oncological trials is doubled in twenty years. Ann Oncol 2009; 20:379-85.

Publisert: 18. november 2010. Tidsskr Nor Legeforen. DOI: 10.4045/tidsskr.10.1153

(C) Tidsskrift for Den norske legeforening 2023. Lastet ned fra tidsskriftet.no 26. april 2023. 